\title{
DO INSTITUTIONAL DISTANCES INFLUENCE SOUTH-SOUTH CROSS-BORDER ACQUISITIONS?
}

\author{
Stephanie Tonn Goulart Moura, Juliano Krug, Christian Falaster ${ }^{1}$ \& lara Regina dos Santos Parisotto \\ Universidade Regional de Blumenau - FURB, Blumenau, SC
}

\begin{tabular}{l} 
ARTICLE DETAILS \\
Article history: \\
Received: 06 de september de 2018 \\
Accepted: 09 de january de 2019 \\
Double Blind Review System \\
Scientific Editor \\
Ilan Avrichir \\
\hline \\
Keywords \\
International Business \\
International Strategy \\
Acquisition \\
Institutional Environment \\
Institutional Distance
\end{tabular}

\begin{abstract}
Different countries have different institutional environments. In this way, multinational companies must deal with the difficulties imposed by the differences between their home environment and that of the country where they are inserted. In this article, we analyze the effects of institutional distance on South-South acquisitions. Specifically, we analyze the effect of institutional distance on the amount of participation chosen in Latin American international acquisitions in Brazil. More specifically, the effect of institutional distance is analyzed through the percentage of shares acquired in international acquisitions. Our results contribute to the theory in international business because it explains why Latin American companies prefer to make total acquisitions even in situations of high institutional distances.
\end{abstract}

\section{INTRODUCTION}

Firms' decisions in their international expansions are determined not only by internal pressures for compliance with organizational standards, but also by the institutional environment, and their conditions (Ferreira \& Serra, 2015). A common form of international expansion is through acquisitions (Chen \& Hennart, 2004; Chari \& Chang, 2009). When facing the decision to carry out an international acquisition, companies need to deal with the strategic decision on how to carry out this acquisition.

Acquisitions may help companies to gain market power, redeploy assets, exploit technical knowledge and increase shareholder value (Nadolska \& Barkema, 2007). Literature emphasizes the challenges and complications of comprehending the potential of acquisitions (Hayward, 2002). Understanding acquisitions can help companies achieve great market power, overcome entry barriers, and have access to new knowledge of market needs and technologies (Vermeulen \& Barkema, 2001; Ahuja \& Katila, 2004). It is perceived that when deciding to enter a market through acquisitions, many variables must be considered. A important variable to be considered is the institutional environment.

Previous studies have shown that when companies decide the percentage of shares to be acquired in a CBA, they consider the institutional environment (Chan \& Makino, 2007), the institutional distance (Pinto, Ferreira, Falaster, Fleury \& Fleury, 2017), the advantages of location (Agarwal \& Ramaswami, 1992), their knowledge acquisition strategies (Ferreira, 2008) and their need for control of operations (Gatignon \& Anderson, 1988). Institutional distances have been shown to be important indicators for understanding the strategic decisions of companies in international acquisitions (Pinto et al., 2017). In general, literature shows that multinationals from developed countries tend to adopt more cautious measures when distances are higher due to the uncertainty of environments (Malhotra, Lin \& Farrell, 2016). However, emerging economies have been increasingly received and 
performed international investments due to the rapid growth and remarkable transformation in the past two decades (Luo \& Tung, 2007). Many of these investments were made in form of cross-border acquisitions, one of the preferred ways for firms to build foreign presence (King et al., 2004).

However, the effects of institutional distance on the choice of participation in international acquisitions are still little known in the case of acquisitions between emerging countries, also known as South-South acquisitions. This research is important because multinationals from emerging countries often have different actions when compared to multinationals from developed countries when considering the way they expand to other emerging countries. Multinationals from emerging countries have advantages linked to knowledge about how to act in countries with less developed institutions and thus can turn disadvantages into advantages in these environments (Cuervo-Cazurra \& Genc, 2008). However, the ways in which multinationals from emerging countries deal with institutional distances are still poorly studied, since the advantages pointed out by Cuervo-Cazurra and Genc (2008) are related to the similarity of the environments and not to considerably different environments. Thus, this study seeks to investigate the effects of institutional distances on the chosen shareholding in South-South acquisitions.

In this paper, we develop theory using the concept of institutional distance. Institutional distances represent the amount of difference between the institutional environment of two countries (Eden \& Miller, 2004). To further break down institutional distances we use the measurements of cross-national distances developed by Berry et al. (2010). Specifically, we analyze facets of institutional distance using the measurements of economic distance, financial distance, political distance, administrative distance, cultural distance and global connectedness distance. Thus, it is possible not only to analyze the impacts of institutional distances but also the specific effects of each type of institutional distance on the strategy of investments.

Methodologically, we used the institutional concept of distances between countries of Berry et al. (2010). We empirically tested the effect of these distances on the amount of participation, that is, the percentage of shares acquired by Latin American companies in acquisitions of Brazilian companies. We used just one country following Fortwengel (2017) argument, going from the premise that different cases of configurations can make institutional distance more or less likely to be considered. Therefore, the findings will be considered regarding the institutional image of Brazil, aiming for a more indepth result. A Thomson-Reuters (SDC Platinum) database was used with a total of 91 acquisitions. The results indicate that, contrary to what was predicted in studies conducted with multinationals from developed countries (Malhotra et al., 2016), international acquisitions of Latin American companies in Brazil have a tendency of larger percentages according to higher administrative, economic, politic, and global connectedness distance.

This study contributes to the understanding of how multinational corporations in emerging countries deal with institutional distances. We contribute to the institution-based view by demonstrating that multinational corporations in emerging countries have the ability to better cope with environments in other emerging countries even when institutional distance is high. This finding has important implications, since it shows that the advantages of emerging country multinationals, when they operate in other emerging countries, may not only be related to the proximity of emerging countries to their institutional characteristics, but also to their ability to adapt to imperfect environments.

\section{THEORETICAL FRAMEWORK}

Institutions are the constraints created by people and they structure political, economic and social interaction. They are composed informal constraints and formal rules (North, 1990). Moreover, it has been created by humans in order to create order and reduce uncertainty when exchanging. In each country, institutions are different because they depend on the institutional environment of each country (North, 1991). Therefore, institutional distance is a form of measuring how different these countries are in order to understand the markets before targeting as a possible acquisition option.

The institutional distance is interpreted by the difference or similarity of the institutions of the countries and these are analyzed when there is intention of foreign investment (Kostova, 1999). The impact of this analysis is in line with organizational strategies, since it broadens the manager's vision by 
showing how the strategy can be combined with the distance in order to achieve the desired competitive advantage (Kostova, 1999; Hernandez \& Nieto, 2015; Gama, Lana, Calixto \& Bandeira-de-Mello, 2016).

Hymer (1960) and Zaheer (1995) postulated that, by finding an environment other than their natural environment, firms would have difficulty operating because of information asymmetry over their competitors, resulting in the "liability of foreignness." Likewise, it is possible to argue that the more different the institutional environment of the country receiving the investment is in relation to the country of origin of the company, the more difficult is the adaptation and the more complicated the operation of the company in that country is.

\section{International Acquisitions and the Institutional Environment}

The institutional dimension has great weight in the determination of foreign investment. This can be explained by the fact that institutional efficiency and quality reduce transnational costs and provide a more stable investment environment. Amal \& Seabra (2007) argue that regional economic agreements involving Latin America are also factors that make emerging economies more attractive to foreign investment. Although, institutional distance might have different impacts due to the variety of rules in each context. Therefore, the impacts of institutional distance can alternate in different cases of configurations, making companies more or less impacted by it (Fortwengel, 2017). Therefore, in order to have a more issue-specific context, the acquisitions considered were only directed to Brazil for a more specific result.

The institutional environment influences the strategic decisions of the companies (Kostova \& Roth, 2002; Meyer, Estrin, Bhaumik, \& Peng, 2009). One of the key strategic decisions to international expansion concerns the choice of ownership share percentage in acquisitions (Chen, 2008; Ferreira, Vicente, Borini \& Almeida, 2017). There are two main forms of international acquisitions. The first is the partial acquisition of a company, also called joint-ventures that have varying acquisition percentages (Agarwal \& Ramaswami, 1992). Joint ventures occur when two or more firms pool together an amount of their resources on a contract with a common legal organization. There are three main reasons to that form of entry: to reduce transaction costs; as a strategic behavior; and for organizational knowledge and learning (Kogut, 1988). The second is the total acquisition of a company, corresponding to the one hundred percent acquisition of the firm (Agarwal \& Ramaswami, 1992). A total acquisition of a firm gives the acquirer a total control of its assets, and therefore it is strategically useful when control is needed.

One of the determining factors of the amount of ownership in an acquisition is the ability to control. The greater the capital acquired in a joint-venture transaction, higher is the control over the investment, while a lower percentage of the acquisition results in shared management, control and results of this subsidiary more shared (Ferreira, 2008). Shared control of the subsidiary has some advantages and disadvantages for the multinational company. While a mode of acquisition with shared capital with the local firm may lead to less control (Gatignon \& Anderson, 1988), multinational companies may use the controller company's remaining shares as a local partnership to develop knowledge and facilitate the process of adaptation to local institutions (Barkema \& Vermuelen, 1998; Meyer et al., 2014).

Companies need to adapt to the local environment to operate (Kostova \& Roth, 2002). In this way, it is expected that there will be costs and difficulties resulting from this adaptation. Companies that must adapt less, that is, come from environments that are similar, will have lower need for adaptation. Companies that do not need to adapt drastically will be able to preserve their organizational structure and practices, having lower adaptation costs and a lower information disadvantage when compared to peers from countries with larger institutional distances. When firms must deal with higher adaptation costs and higher information asymmetry in an environment, these additional costs will result in higher risks regarding the investment.

Investments with higher risks tend to be conducted using partial acquisitions in order to reduce capital commitment and mitigate some of the associated risk (Chen, 2008). We hence develop the baseline hypothesis of our study:

Baseline Hypothesis: The greater the institutional distance between the country of origin and Brazil, the lower the percentage of capital acquisition.

Several factors are involved in the decisionmaking of companies regarding international expansion, and the possibility of applying resources are diverse, such as total acquisitions or joint- 
ventures, among other forms of internationalization (Agarwal \& Ramaswami, 1992). The administrative distance between one country and another, created by Berry et al. (2010), refers to the administrative standards that govern a country through its bureaucracy, religion, current legal system, colonial historical traits and its language. The differences related to these aspects are studied over time (Wolf \& Weinschrott, 1973; Whitley, 1992; Henisz, 2000) and are influential in the process of adapting organizations to the foreign environment in which they are inserted.

The difficulties of establishing a network, market, and trade promotion, as well as the effective application of the knowledge that companies possess, become barriers in establishing subsidiaries in administratively distant countries (Chiswick \& Miller, 1998). Distance between two countries can increase when there is an absence of shared monetary or political association, political hostilities, and weak legal and financial institutions (Ghemawat, 2001). These administrative differences will represent more complex adaptations to be made in order to properly operate in the country. When a higher administrative distance is present, the percentage of capital acquisition will be lower because of higher perceived adaptation costs and therefore higher risks with the investment. Thereafter, we propose the following hypothesis regarding administrative institutional distance:

Hypothesis 01: The greater the institutional administrative distance between the country of origin and Brazil, the lower the percentage of capital acquisition.

The way to internationalize also suffers the influence of the culture when related to the strategic decisions that involve the whole process. Cultural aspects interact with the external market and influence the way companies enter, determining the strategies adopted in the internationalization of markets (Werner, 2002; Brewer, 2007). Cultural distances have the dimension of individualism, masculinity and distance from power proposed by Hofstede (1991). They measure inequality in relation to power, the link between people and their individuality, and the role of masculinity through values and history.

Non-formal structures belonging to localities can be defined by norms, culture and ethics (Meyer et al., 2009). Dominant values in societies constantly evolve (Inglehart \& Baker, 2000) and modify people's behavior in business transactions. As such, cultural differences between countries play a key role in adapting new enterprises and developing new businesses. The culture, in this way, is a determinant of the way firms will enter the market (Barkema et al., 1996), in order to reduce or increase the uncertainties proportionate to the difference between countries. Therefore, when the cultural distance is high, firms' strategies to enter the market may differ if considering the uncertainties provided from the cultural differences of the country. Moreover, it is expected that when uncertainties are high, the percentage of capital acquisition might be low, as proposed in our hypothesis:

Hypothesis 02: The greater the institutional cultural distance between the country of origin and Brazil, the lower the percentage of capital acquisition.

Emerging countries like Brazil have institutional inefficiencies that do not allow perfect competition in the market (Peng, Sun, Pinkham \& Chen, 2009). The economic indicators of the nations are recognized in several studies as indexes that measure the economic stability of the countries, and also shape the way the country's economy interacts with the external market (Caves, 1996). These differences often lead to adaptation costs and uncertainty environments for organizations (Berry et al., 2010). Starting from this assumption it is necessary to consider the economic perspective when analyzing the strategies involving companies, mainly in emerging countries.

Thus, the choice of firms' entry into foreign markets is directly influenced by the distances between countries' economic indicators (Zaheer \& Zaheer, 1997). The country's economic development, measured by macroeconomic indicators such as GDP, is a measure that can be used in the analysis of whether to invest and how to invest (Campa \& Guillén, 1999), in an attempt to reduce the risks and uncertainties inherent in this process. Therefore, smaller institutional distances facilitate the internationalization process and corroborate with the predictability of investments, whereas otherwise the way of organizations' entry mode tend to be more cautious due to the lack of economic stability. As these economic distances are related to the economic development of a nation and its macroeconomic characteristics (Whitley, 1992; Caves, 1996), we may expect that countries which are similar in its development condition will represent lower risks and adaptation costs. Thus, when higher 
institutional economic distance is present between the countries, the need of a careful market analysis will be higher, risks and adaptation cost will be higher and thus, the percentage of capital acquisition should be lower, as we develop on our following hypothesis.

Hypothesis 03: The greater the institutional economic distance between the country of origin and Brazil, the lower the percentage of capital acquisition.

Political distance increases uncertainty generated by international investment in different countries. The central assessment of a country's political issues in the international business literature lies in the way politics is formed through democratic or autocratic regimes and in relation to the country's political positioning vis-à-vis the international economy (Henisz, 2000; Henisz \& Williamson, 1999; Whitley, 1992). These issues directly interact with the countries' economic and financial stability and can influence foreign investment strategies.

The choice of entry mode into internationalization, as well as the choice of the foreign market in which one wishes to invest are linked to the political dimension of institutional distances (Henisz \& Delios, 2000).

Minority acquisitions are prioritized so that companies can acquire local knowledge and learn how to do business (Ferreira, 2008).

Asymmetry of information inherent to the process is minimized and the adaptation to political questions is gradual. Differences in political stability, trade bloc membership, and democracy (Henisz, 2000; Henisz \& Williamson, 1999; Whitley, 1992) will then play an important role for companies to understand how different the political dimension within the country is. It is likely that political institutional distance may impose a tendency for firms to develop strategies of entry mode that allow them to better understand the political environment and its risks before larger resource commitments. Therefore, we propose that:

Hypothesis 04: The greater the institutional political distance between the country of origin and Brazil, the lower the percentage of capital acquisition.

The financial distance between countries is identified by the way financial systems are designed and the availability of credit that is provided to organizations (Porta, Lopez-de-Silianes, Schleifer \& Vishny, 1998). The financial distance corresponds to the differences of the financial sector of the country and is measured by the data of the domestic economy in comparison to the international indices, the metric is based on the percentage of GDP and the composition of international financial systems (Berry et al., 2010).

Financial similarity among nations can facilitate the adaptation of firms to the financial institutional environment and reduce uncertainty from these interactions (Cuervo-Cazurra \& Dau, 2009). Hence, we propose:

Hypothesis 05: The greater the institutional financial distance between the country of origin and Brazil, the lower the percentage of capital acquisition.

The connectivity of a nation with the rest of the world represents how much a country interacts with other countries.

The impact generated by the global connectedness distance concerns the availability of information and diffusion about the activities of the country around the world (Oxley \& Yeung, 2001). The measurement of connectedness distance is characterized by the amount of investment in tourism and international tourism, based on national GDP, and by the number of users who have access to the internet in the country.

The intensity in which individuals and firms interact with external markets demonstrates the nation's accessibility to its exterior (Berry et al., 2010). If the country is inaccessible for international relations, foreign companies may have more difficulties to internationalize to that market. Differences in country connectivity with the world can influence the behavior of organizations facing these markets, modifying their strategies and their entry mode.

Therefore, countries with greater disparities in the amount of internet users and tourism activities will represent a greater global connectedness distance. Countries with high connectivity distance will represent higher cost of information, representing higher adaptation costs and a tendency for lower percentages of acquisitions in order to maintain a local partner and mitigate these costs. Hence, we present the following hypothesis:

Hypothesis 06: The greater the institutional global connectedness distance between the country of origin and Brazil, the lower the percentage of capital acquisition.

The model created for the present study is therefore composed by six hypothesis, which is read by expecting a negative influence in the amount 
chosen on CBA due to each of the six institutional distances proposed in this study:

Figure 1-Model Proposed

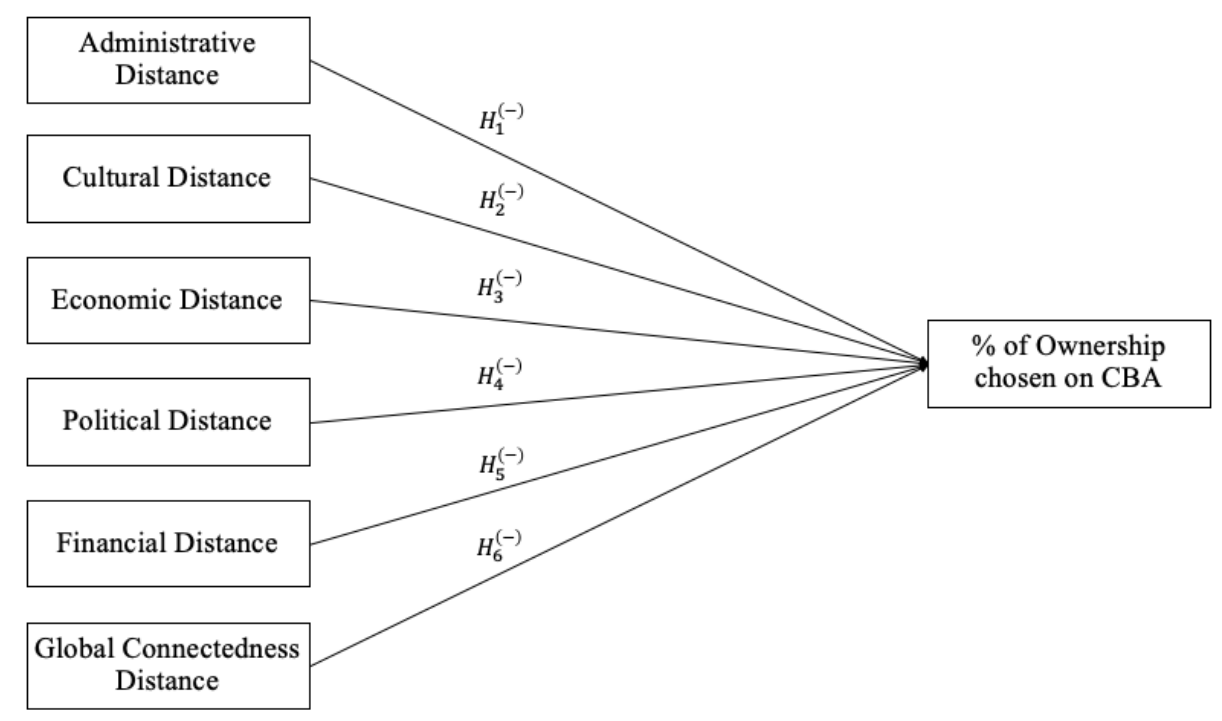

Source: Prepared by the authors.

\section{METHODOLOGICAL PROCEDURES}

Methodologically, this study based on a quantitative research of confirmatory character and longitudinal cut. We assume a positivist perspective, with multiple linear regressions, with the purpose of testing the predetermined hypotheses. The study has a longitudinal feature because it aims to analyze, over the course of ten years, the same sample elements. The database used in the survey is Thomson-Reuters SDC Platinum, with data from Latin American acquisitions targeting Brazil. For independent variables, we collected data from the crossnational distances of Berry et al. (2010). The analysis of these data focuses on the influence of the institutional distance, using six cross-national distance dimensions, in the percentage of ownership chosen in the acquisition. The context of Latin America can help to explain phenomena related to developing economies, which have institutional deficiencies that distinguish them from the developed economies (Cuervo-Cazurra \& Dau, 2009; Cuervo-Cazurra, 2016). In addition, Latin American firms share similarities, context and historic background (Khoury, Junkunc \& Mingo, 2015; Pinto et al., 2017) and could shows specific institutional changes among the years.

The Latin American countries that comprise the study sample are Argentina (23\%), Chile (31\%), Colombia (15\%), Costa Rica (1\%), Mexico (28\%), and Venezuela (2\%). Together, the countries correspond to 91 records of international acquisitions, targeting firms in Brazil during the ten years of the study, from 2005 to 2015. Table 1 describes the variables used.

Table 1 - Description of Variables

\begin{tabular}{|c|c|c|}
\hline Variable Type & Variable Name & Theoretical Framework \\
\hline Dependent Variable & Acquisition Percentage & $\begin{array}{l}\text { Chen \& Hennart (2004) } \\
\text { Chari \& Chang (2009) }\end{array}$ \\
\hline $\begin{array}{l}\text { Independent } \\
\text { Variables }\end{array}$ & $\begin{array}{l}\text { Administrative Distance } \\
\text { Cultural Distance } \\
\text { Economic Distance } \\
\text { Political Distance } \\
\text { Financial Distance } \\
\text { Global Connectedness Distance } \\
\end{array}$ & $\begin{array}{c}\text { Anderson (1979) } \\
\text { Whitley (1992) } \\
\text { Nelson \& Rosenberg (1993) } \\
\text { Berry et al. (2010) }\end{array}$ \\
\hline Control Variables & $\begin{array}{l}\text { Total Assets of the Acquired Company } \\
\text { Transaction Value } \\
\text { Year of Acquisition } \\
\text { Industry of the Acquirer Company } \\
\text { Industry of the Acquired Company }\end{array}$ & $\begin{array}{l}\text { Aybar \& Ficici (2009) } \\
\text { Pinto et al. (2017) }\end{array}$ \\
\hline
\end{tabular}

Source: Prepared by the authors. 
The dependent variable of the study is the percentage of ownership chosen for the acquisition of the capital in Brazilian companies. The measure of this variable is appropriate for the study because it considers all the percentage values of acquisition and not only if the acquisition is total or partial, allowing a more fine-grained analysis of the effects (Chen \& Hennart, 2004; Chari \& Chang, 2009).

We used the cross-national distances established by Berry et al. (2010) as to assess institutional distances. For each distance, we used its natural logarithm form in order to normalize data and avoid problems of heteroscedasticity. Specifically, we chose administrative distance, cultural distance, economic distance, political distance, financial distance and global connectedness distance. These six distances were tested independently and together, in order to test if they influence the ownership chosen in Latin American acquisitions in Brazil.

Administrative distance reflects differences across language, religion, legal system and colonial ties (Berry et al., 2010). Cultural distance measures the differences between levels of authority, trust, individuality and importance of work and family. Economic distance represents the difference of macroeconomic indicators between countries (Berry et al., 2010). Political distance measures de difference in politics as a regulatory institution (Dikova \& Van Witteloostuijn, 2007), it involves democracy, political ties and trade relationships (Berry et al., 2010). Financial distance measures the difference between the structures of financial institutions. Finally, global connectedness shows the differences in the level of integration of the country to the world (Ferreira et al., 2017).

We used several control variables in order to absorb potential variability of alternative answers. We controlled for the value of the transaction, the size of the company acquired, and the industry of the acquiring company and the acquired company, to control the effects and covariates that may influence the acquisition percentage (Buckley et al., 2016; Ferreira et al., 2017). Therefore, the year of the acquisition was used as a control variable, controlling for business cycles. The value of the transaction and the size of the acquired company control for the fact that larger transactions have direct consequences on the financial costs of the acquisitions, we used dollar value of the transaction and dollar value of the assets of the target company to build these variables, both using millions of dollars (Aybar \& Ficici, 2009). Finally, we controlled for the industry of acquirer and target firms using dummy variables for each macro-industry (Consumer Products and Services, Consumer Staples, Energy and Power, Financials, Healthcare, High Technology, Industrials, Materials, Media and Entertainment, Retail, Telecommunications) to control for possible industry fads and standard procedures (Buckley et al., 2016). Industry was classified as dummy by each macro industry sector. All these data extracted from the Thomson-Reuters SDC Platinum database, per acquisition.

\section{ANALYSIS OF THE RESULTS}

In Table 2 it is possible to analyze the descriptive statistics of the research data.

Table 2 - Descriptive Statistics

\begin{tabular}{l|c|c|c|c|c}
\hline & N & Minimum & Maximum & Mean & $\begin{array}{c}\text { Standard } \\
\text { Deviation }\end{array}$ \\
\hline Acquisition Percentage & 91 & 13,43 & 100,00 & 83,25 & 25,18 \\
\hline Administrative Distance & 91 & 41,92 & 48,29 & 44,88 & 2,41 \\
\hline Cultural Distance & 91 & 1,20 & 6,22 & 2,78 & 1,25 \\
\hline Economic Distance & 91 & 0,05 & 1,62 & 0,50 & 0,39 \\
\hline Political Distance & 91 & 60,11 & 237,55 & 191,09 & 67,74 \\
\hline Financial Distance & 91 & 0,06 & 1,28 & 0,65 & 0,37 \\
\hline Global Connectedness Distance & 91 & 0,09 & 2,68 & 1,02 & 0,78 \\
\hline Total Assets of the Acquired & 91 & 19,62 & 111186,50 & 7736,44 & 11779,75 \\
Company & 91 & 0,60 & 3425,19 & 344,96 & 505,22 \\
\hline Transaction Value & & & &
\end{tabular}

Source: Prepared by the authors based on the research data. 
Table 3 presents the results of the correlations between the study variables. During the statistical tests, there were some high correlations between our independent variables, hence we performed a VIF test, presented in Table 4, which did not result in multicollinearity problems using the standard limit of 10 for VIF developed by Hair et al. (1995). We performed the Glejser test in order to detect possible heteroscedasticity and results were negative. Results of our regression models are also present in Table 3.

Table 3 - Correlations

\begin{tabular}{l|l|l|l|l|l|l|l|l|l}
\hline & Acq. $\%$ & 1 & 2 & 3 & 4 & 5 & 6 & 7 \\
\hline 1 & Administrative Distance &, $267^{*}$ & 1 & & & & & & \\
\hline 2 & Cultural Distance & 0,038 & $-0,126$ & 1 & & & & & \\
\hline 3 & Economic Distance &, $314^{* *}$ &, $824 * *$ & $-0,073$ & 1 & & & & \\
\hline 4 & Political Distance & 0,192 &, $627^{* *}$ & $-0,024$ &, $594^{* *}$ & 1 & & & \\
\hline 5 & Financial Distance & 0,123 &, $228^{*}$ & 0,132 & 0,163 & $-0,094$ & 1 & & \\
\hline 6 & $\begin{array}{l}\text { Global Connectedness } \\
\text { Distance }\end{array}$ &, $335^{* *}$ &, $695^{* *}$ & 0,038 &, $674^{* *}$ &, $666^{* *}$ & 0,107 & 1 & \\
\hline 7 & $\begin{array}{l}\text { Total Assets of the Acquired } \\
\text { Company }\end{array}$ & $-0,06$ &,$- 248^{*}$ &, $392 * *$ & $-0,159$ & $-0,048$ & $-0,094$ & $-0,065$ & 1 \\
\hline 8 & \begin{tabular}{l} 
Transaction Value \\
\hline
\end{tabular} & 0,047 & $-0,023$ & 0,109 & 0,06 & 0,103 & $-0,096$ & $-0,009$ & 0,165 \\
\hline
\end{tabular}

Source: Prepared by the authors based on the research data.

In order to test the baseline hypothesis of this article, we performed a multiple linear regression test, testing the effect of each type of institutional distance on the acquisition percentage. The multiple linear regression performed and presented in table 4 . Model 1 includes only the control variables. From models 2 to 7 , we tested the independent variables, one by one, and model 8 test all variables together.

In model 2, the administrative distance variable was tested and the results indicate a positive and significant result between the distance and the percentage of capital acquisition $(0.273$; $p<0.05)$ contradicting the hypothesis 1 that predicted a negative effect. Thus, the hypothesis created based on the theory is not confirmed since it was found that the greater the administrative distance, the greater the percentage of investment. Administrative distance is not significant when tested with all variables in model 8.

In model 3, we tested the cultural distance and its effects on the percentage of acquisition.

A non-significant coefficient obtained for the relation. In this way, it was verified the lack of effect of cultural distance on the dependent variable. Therefore, this goes against the findings of some studies (Kogut \& Singh, 1988; Hennart \& Larimo, 1998; Barkema et al., 1996) that found that the characteristics of national cultures and its differences have effect on the selection of entry choice when internationalizing. This nonsignificant effect may be due to a relatively small cultural distances between countries of Latin America and Brazil. In model 4, the economic distance was tested and the results indicate significance in relation to the acquisition of ownership $(0.342 ; p<0.01)$. This result indicates that the greater the distance from economic factors such as per capita GDP, export, import and inflation rates, the greater will be Latin American foreign direct investment in Brazil. Therefore, the influence is positive, again contradicting the hypothesis that formulated basis of the theory.

In model 5, the tests were applied at the political distance and this relationship had a significant positive effect on the dependent variable $(0.276$; $p<0.05)$.

This analysis may indicate that the policy measures of the emerging countries studied here influence business within Latin America. Brazil, as a recipient of these investments, even though it has a chair in Mercosur, the economic bloc that was ruling during the years studied, and which has as a member some countries also included in this research, has a relevant political institutional distance. Similarly, Kraus, Ambos \& Eggers (2015) have found that political distance are primary drivers of risk perceptions when deciding the mode of entry in the country.

In model 6 the financial distance was tested and its results were also not significant for the research. This result may also indicate that financial disparities may not be as relevant as, for instance, the quality of the financial system of the host country, as pointed in studies as Khanna \& Palepu (2000). In model 7 the global connectedness distance was tested in relation to the 
percentage of acquisition in the transactions studied. The result of this analysis was positive and shows a positive relation to our dependent variable $(0.385$; $\mathrm{p}<0.01)$. The result indicates that the greater the global connectedness distance, the greater the percentage of acquisition in the Latin American transactions in Brazil, which contradicts our hypothesis based on theory.

Table 4-Regression Results

\begin{tabular}{|c|c|c|c|c|c|c|c|c|c|}
\hline & 1 & 2 & 3 & 4 & 5 & 6 & 7 & 8 & VIF \\
\hline Administrative Distance & & $0,273 *$ & & & & & & 0,117 & 8,446 \\
\hline Cultural Distance & & & $-0,099$ & & & & & 0,103 & 2,659 \\
\hline Economic Distance & & & & $0,342 * *$ & & & & $0,491 *$ & 4,966 \\
\hline Political Distance & & & & & $0,276^{*}$ & & & $-0,325$ & 6,349 \\
\hline Financial Distance & & & & & & $-0,041$ & & $-0,566^{*}$ & 7,432 \\
\hline $\begin{array}{l}\text { Global Connectedness } \\
\text { Distance }\end{array}$ & & & & & & & $0,385 * *$ & $0,356^{*}$ & 2,858 \\
\hline $\begin{array}{l}\text { Total Assets of the Acquired } \\
\text { Company }\end{array}$ & $-0,051$ & $-0,028$ & $-0,028$ & $-0,072$ & $-0,027$ & $-0,056$ & $-0,051$ & $-0,189$ & 1,781 \\
\hline Transaction Value & $-0,054$ & $-0,060$ & $-0,048$ & $-0,073$ & $-0,079$ & $-0,052$ & $-0,058$ & $-0,034$ & 1,302 \\
\hline Year of Acquisition & YES & YES & YES & YES & YES & YES & YES & YES & - \\
\hline $\begin{array}{l}\text { Industry of the Acquiror } \\
\text { Company }\end{array}$ & YES & YES & YES & YES & YES & YES & YES & YES & - \\
\hline $\begin{array}{l}\text { Industry of the Acquired } \\
\text { Company }\end{array}$ & YES & YES & YES & YES & YES & YES & YES & YES & - \\
\hline $\mathrm{F}$ & 0,661 & 0,859 & 0,648 & 1,005 & 0,861 & 0,628 & 1,031 & 1,139 & 1,139 \\
\hline $\mathrm{R}^{2}$ & 0,194 & 0,248 & 0,199 & 0,279 & 0,249 & 0,195 & 0,284 & 0,363 & 0,363 \\
\hline
\end{tabular}

The dependent variable is the acquisition percentage.

$+=p<0.1 ;^{*}=p<0.05 ; * *=p<0.01$;

Source: Prepared by the authors based on the research data.

Of all variables tested in multiple linear regressions, only the administrative, economic, political, and global connectedness distance had a significant influence on their results. The greater the distance of these variables, the greater the foreign investment in Brazil. This result contradicts the baseline hypothesis, as well as hypotheses 01, 03, 04 and 06 postulated, which foresaw a tendency for acquisitions of lower percentages when institutional distance is greater.

\section{CONCLUSIONS}

The institutional distance measures developed by Berry et al. (2010) intend allow the analysis of the differences between the institutions of countries. In this way, this article had as main objective to analyze the effect of institutional distances on the percentage of shares acquired in Latin American international acquisitions directed to Brazil. This percentage of ownership acquisition derives from the internationalization strategies as a response to the environments.

A greater institutional distance between the country of the acquiring company and the country of the acquired company, that is, the more different the institutional environments, results in greater uncertainties and a higher need of adaptation to the environment (Meyer et al., 2014). Thus, we developed six hypotheses proposing that companies from countries with greater institutional distances would opt for an acquisition strategy with a smaller amount of the percentage of shares. With a smaller number of shares acquired in the acquisition, companies retain a local partner who could help them learn to cope with the environment. In an empirical way, we analyze how six of the variables regarding institutional distances of Berry et al. (2010) would influence the percentage of acquisition in the context of Latin America. 
Our results show that, on the contrary to what the hypotheses postulated expected, the larger institutional distances triggered higher percentage in the purchase of shares in the acquisitions directed to Brazil. The variables that confirmed this relationship were the administrative, political, economic, and global connectedness distance, showing significance when tested alone and altogether with the other variables.

It is possible to confirm that institutional distances influence the way in which Latin American companies make acquisitions in Brazil and formulate their internationalization strategies. However, on the contrary to preferred modes of smaller ownership, companies prefer greater participation when dealing with environments with larger institutional distances. A first explanation for this rather counterintuitive result is that companies that face high institutional distances may prefer stock control to ensure the possibility of more agile strategic responses rather than maintaining a local partner with whom they would have to negotiate the answers. Similar evidences have already been found in works such as Falaster and Ferreira (2017), regarding environments with high arbitrary institutional inefficiencies and Pinto et al. (2017) with Brazilian acquisitions abroad. This finding supports the results of Gaur and Lu (2007), which also found that in institutionally distant countries, subsidiaries have better survival probabilities when foreign parents have more ownership.

A second explanation for the higher amount of ownership chosen with higher institutional distances is based on our context of study. In this study, we only analyzed Latin American acquisitions in Brazil. In emerging countries, institutional inefficiencies are greater when compared to developed countries (Cuervo-Cazurra \& Dau, 2009). The countries of Latin America have an inefficient bureaucratic system that promotes distrust among economic and social actors. Firms that have had to deal with these inefficient environments throughout their whole existence may be more prepared to deal with uncertainties because they are used to dealing with uncertainties. Works as Cuervo-Cazzura and Genc (2008) showed that firms that are used to an inefficient institutional environment have less problems when dealing with similar environments. We defend that a similar effect happens when firms from inefficient environments face higher institutional inefficiencies. Instead of pursuing a more conservative path and acquiring a lower amount of ownership, firms that come from inefficient environments may be able to deal with the uncertainty provided by institutional distances more easily, being able to follow fewer conservative paths.

A third explanation is due to the asymmetry of institutional distances. When firms of highly inefficient institutional environments, as for instance, Bolivia, invest in an emerging economy as Brazil the institutional distance is the same found by Brazilian firms investing in Bolivia. However, Brazil has a far more developed institutional environment than Bolivia, so that Brazilian firms will perceive higher risks of operating in Bolivia than Bolivian firms will perceive in operating in Brazil. These asymmetries are found in our study. Brazil has one of the most developed institutional environments in Latin America while the majority of other countries are 'climbing up the ladder' when investing in Brazil rather than investing in a country where the environment is worst than their home institutions.

Understanding the effects of institutional distances on Latin American acquisitions is an important contribution to the literature for two main reasons. First, a better understanding of the factors influencing the ownership percentage decisions made in Latin American acquisitions helps to theoretically develop the discussion between the need to adapt to the local environment and the need to control the company's actions in its strategic design. The second contribution is in the sense of an institution-based view. The understanding of the positive effect of institutional distances on the shareholding chosen by companies in their acquisitions demonstrates that there is an effect of the difference between the environments in the strategic decisions of the companies. In addition, this effect is perceived as positive, indicating that Latin countries may have different strategic tendencies than the ones that could be seen in firms from developed countries.

This study has two main limitations. The first is the use of acquisitions exclusively directed to Brazil as the object of analysis. The use of acquisitions directed only to Brazil represents a limitation because results may be different if considered in all Latin American economies. It is possible to develop future research in order to add the other Latin nations in the empirical analyzes to reduce this limitation.

In addition, the second limitation is linked to the very characteristic of institutional distance as a 
measure of the difference between countries. Institutional distance shows how different countries are to institutional factors but does not demonstrate the nature of this difference. For example, one country that has a very high economic gap over another may represent a large difference in GDP between these countries. However, it is uncertain

\section{REFERENCES}

Agarwal, S., \& Ramaswami, S. N. (1992). Choice of foreign market entry mode: Impact of ownership, location and internalization factors. Journal of International Business Studies, 23(1), 1-27.

Ahuja, G. and Katila, R. (2004) 'Where do resources come from? The role of idiosyncratic situations', Strategic Management Journal 25(8/9): 887-908.

Amal, M., \& Seabra, F. (2007). Determinantes do investimento direto externo (IDE) na América Latina: uma perspectiva institucional. Revista economia, 8(2), 231-247.

Aybar, B., \& Ficici, A. (2009). Cross-border acquisitions and firm value: An analysis of emergingmarket multinationals. Journal of International Business Studies, 40(8), 1317-1338.

Barkema, H. G., Bell, J. H., \& Pennings, J. M. (1996). Foreign entry, cultural barriers, and learning. Strategic management journal, 17(2), 151-166.

Barkema, H., \& Vermeulen, F. (1998). International expansion through start-up or acquisition: A learning perspective. Academy of Management Journal, 41(1), 726.

Berry, H., Guillén, M. F., \& Zhou, N. (2010). An institutional approach to cross-national distance. Journal of International Business Studies, 41(9), 14601480.

Brewer, P. A. (2007). Operationalizing psychic distance: A revised approach. Journal of International Marketing, 15(1), 44-66.

Campa, J., \& Guillén, M. F. (1999). The internalization of exports: Firm-and location-specific factors in a middle-income country. Management Science, 45(11), 1463-1478.

Caves, R. E. 1996. Multinational enterprise and economic analysis. New York: Cambridge University Press.

Chan, C., \& Makino, S. (2007). Legitimacy and multilevel institutional environments: Implications for foreign subsidiary ownership structure. Journal of International Business Studies, 38(4), 621-638. whether the effects of distance would be the same as the country with the highest GDP for the country with the lowest GDP and vice-versa. Future research could develop this concept to contribute not only to institutional distance but also to a version of distance based on the increasing or decreasing sense of institutional difference between countries.

Chari, M., \& Chang, K. (2009). Determinants of the share of equity sought in cross-border acquisitions. Journal of International Business Studies, 40(8), 12771297

Chen, S. (2008). The motives for international acquisitions: Capability procurements, strategic considerations, and the role of ownership structures. Journal of International Business Studies, 39(3), 454471.

Chen, S. F. S., \& Hennart, J. F. (2004). A hostage theory of joint ventures: why do Japanese investors choose partial over full acquisitions to enter the United States? Journal of Business Research, 57(10), 11261134.

Chiswick, B. R., \& Miller, P. W. (1998). Census language questions in North America. Journal of Economic and Social Measurement, 25(2), 73-95.

Cuervo-Cazurra, A. (2016). Multilatinas as sources of new research insights: The learning and escape drivers of international expansion. Journal of Business Research, 69(6), 1963-1972.

Cuervo-Cazurra, A., \& Dau, L. A. (2009). Promarket reforms and firm profitability in developing countries. Academy of Management Journal, 52(6), 1348-1368.

Cuervo-Cazurra, A., \& Genc, M. (2008). Transforming disadvantages into advantages: Developing-country MNEs in the least developed countries. Journal of International Business Studies, 39(6), 957-979.

Dikova, D., \& Van Witteloostuijn, A. (2007). Foreign direct investment mode choice: entry and establishment modes in transition economies. Journal of international business studies, 38(6), 1013-1033.

Eden, L., \& Miller, S. R. (2004). Distance matters: Liability of foreignness, institutional distance and ownership strategy. In " Theories of the Multinational Enterprise: Diversity, Complexity and Relevance" (pp. 187-221). Emerald Group Publishing Limited.

Falaster, C. \& Ferreira, MP. (2017) The Effects of Pervasive and Arbitrary Institutional Inefficiencies on the Ownership Acquired in Cross-Border Acquisitions. Artigo apresentado no EnAnpad 2017. Anais do EnAnpad 2017. São Paulo, Brasil. 
Ferreira, M. (2008). Building and leveraging knowledge capabilities through cross-border acquisitions. In Tallman, S. (Ed.), New Generation in International Strategy. New York, NY: Edward Elgar Publishing.

Ferreira, M. P., \& Serra, F. R. (2015). Abordagem conceitual às estratégias de internacionalização sobre pressões institucionais duais para legitimidade e conformidade. Revista de Administração ContemporâneaRAC, 19(4).

Ferreira, M., Vicente, S., Borini, F., \& Almeida, M. (2017). Degree of equity ownership in cross-border acquisitions of Brazilian firms by multinationals: a strategic response to institutional distance. Revista de Administração. 52(1), 59-69.

Fortwengel, J. (2017). Understanding when MNCs can overcome institutional distance: A research agenda. Management International Review, 57(6), 793-814.

Gama, M.A.B., Lana, J., Calixto, C.V., \& Bandeira-deMello, R. (2016). Internacionalização de business group: a escolha do país de destino pela distância institucional. Revista Brasileira de Gestão de Negócios, 18(61).

Gatignon, H., \& Anderson, E. (1988). The multinational corporation's degree of control over foreign subsidiaries: An empirical test of a transaction cost explanation. Journal of Law, Economics \& Organization, 4(2), 305-336.

Gaur, A. S., \& Lu, J. W. (2007). Ownership strategies and survival of foreign subsidiaries: Impacts of institutional distance and experience. Journal of management, 33(1), 84-110.

Ghemawat, P. (2001). Distance still matters. Harvard business review, 79(8), 137-147.

Guler, I., \& Guillén, M. F. (2010). Institutions and the internationalization of US venture capital firms. Journal of International Business Studies, 41(2), 185-205.

Hair, J. F. Jr., Anderson, R. E., Tatham, R. L. \& Black, W. C. (1995). Multivariate Data Analysis (3rd ed). New York: Macmillan.

Hayward, M.L.A. (2002) 'When do firms learn from their acquisition experience? Evidence from 1990 to 1995', Strategic Management Journal 23(1): 21-39.

Henisz, W. J. (2000). The institutional environment for multinational investment. The Journal of Law, Economics, and Organization, 16(2), 334-364.

Henisz, W. J., \& Delios, A. (2000). Learning about the institutional environment. In The new institutionalism in strategic management (pp. 339-372). Emerald Group Publishing Limited.
Henisz, W. J., \& Williamson, O. E. 1999. Comparative economic organization - Within and between countries. Business and Politics, 1(3): 261-277.

Hennart, J. F., \& Larimo, J. (1998). The impact of culture on the strategy of multinational enterprises: does national origin affect ownership decisions?. Journal of International Business Studies, 29(3), 515538.

Hernandez, V., \& Nieto, M. J. (2015). The effect of the magnitude and direction of institutional distance on the choice of international entry modes. Journal of World Business, 50.

Hofstede, G. (1991). Cultures and organizations. Intercultural cooperation and its importance for survival. Software of the mind. London: Mc Iraw-Hill.

Hymer, S. (1960). The international operations of national firms: a study of Direct Investment, unpublished Ph. D (Doctoral dissertation, dissertation. Massachusetts Institute of Technology).

Inglehart, R., \& Baker, W. E. (2000). Modernization, cultural change, and the persistence of traditional values. American sociological review, 19-51.

Khanna, T., \& Palepu, K. (2000). Is group affiliation profitable in emerging markets? An analysis of diversified Indian business groups. The Journal of Finance, 55(2), 867-891.

King, D. R., Dalton, D. R., Daily, C. M., \& Covin, J. G. (2004). Meta-analyses of post-acquisition performance: Indications of unidentified moderators. Strategic management journal, 25(2), 187-200.

Kogut, B. (1988). Joint ventures: Theoretical and empirical perspectives. Strategic management journal, 9(4), 319-332.

Kogut, B., \& Singh, H. (1988). The effect of national culture on the choice of entry mode. Journal of international business studies, 19(3), 411-432.

Kostova, T. (1999). Transnational transfer of strategic organizational practices: A contextual perspective. Academy of Management Review, 24.

Kostova, T., \& Roth, K. (2002). Adoption of an organizational practice by subsidiaries of multinational corporations: Institutional and relational effects. Academy of management journal, 45(1), 215-233

Kraus, S., Ambos, T. C., Eggers, F., \& Cesinger, B. (2015). Distance and perceptions of risk in internationalization decisions. Journal of Business Research, 68(7), 1501-1505. 
Luo, Y., \& Tung, R. L. (2007). International expansion of emerging market enterprises: A springboard perspective. Journal of International Business Studies, 38(4), 481-498.

Malhotra, S., Lin, X., \& Farrell, C. (2016). Crossnational uncertainty and level of control in cross-border acquisitions: A comparison of Latin American and US multinationals. Journal of Business Research, 69(6), 1993-2004.

Meyer, K., Ding, Y., Li, J., \& Zhang, H. (2014). Overcoming distrust: How state-owned enterprises adapt their foreign entries to institutional pressures abroad. Journal of International Business Studies, 45(8), 1005-1028.

Meyer, K., Estrin, S., Bhaumik, S., \& Peng, M. (2009). Institutions, resources, and entry strategies in emerging economies. Strategic Management Journal, 30(1), 6180.

Miller, D. (1979). Strategy, structure and environment: Context influences upon some bivariate associations. Journal of Management Studies, 16(3), 294-316.

Mintzberg, H., Ahlstrand, B., \& Lampel, J. (2010). Safári de estratégia: um roteiro pela selva do planejamento estratégico. 2. ed. Porto Alegre: Bookmann.

Nadolska, A., \& Barkema, H. G. (2007). Learning to internationalise: the pace and success of foreign acquisitions. Journal of International Business Studies, 38(7), 1170-1186.

North, D. C. (1991). Institutions. Journal of economic perspectives, 5(1), 97-112.

Oxley, J. E., \& Yeung, B. (2001). E-commerce readiness: Institutional environment and international competitiveness. Journal of International Business Studies, 32(4), 705-723.
Peng, M. W., Sun, S. L., Pinkham, B., \& Chen, H. (2009). The institution-based view as a third leg for a strategy tripod. Academy of Management Perspectives, 23(3), 6381.

Pinto, C. F., Ferreira, M. P., Falaster, C., Fleury, M. T. L., \& Fleury, A. (2017). Ownership in cross-border acquisitions and the role of government support. Journal of World Business, 52(4), 533-545.

Porta, R. L., Lopez-de-Silanes, F., Shleifer, A., \& Vishny, R. W. (1998). Law and finance. Journal of political economy, 106(6), 1113-1155.

Slangen, A. H., \& Hennart, J. F. (2008). Do multinationals really prefer to enter culturally distant countries through greenfields rather than through acquisitions? The role of parent experience and subsidiary autonomy. Journal of International Business Studies, 39(3), 472-490.

Vermeulen, F. and Barkema, H.G. (2001) 'Learning through acquisitions', Academy of Management Journal 44(3): 457-476.

Werner, S. (2002). Recent developments in international management research: A review of 20 top management journals. Journal of Management, 28(3), 277-305.

Whitley, R. (1992). Business systems in East Asia: Firms, markets and societies. Sage.

Wolf, C., \& Weinschrott, D. (1973). International Transactions and Regionalism: Distinguishing" insiders" from" outsiders". The American Economic Review, $63(2), 52-60$.

Zaheer, S. (1995). Overcoming the liability of foreignness. Academy of Management journal, 38(2), 341-363.

Zaheer, S., \& Zaheer, A. (1997). Country effects on information seeking in global electronic networks. Journal of International Business Studies, 28(1), 77-100. 


\section{SOBRE OS AUTORES}

- $\quad$ Stephanie Tonn Goulart Moura - Universidade Regional de Blumenau - FURB, Santa Catarina, (Brasil). Email: stephaniemr600@gmail.com Orcid id: https://orcid.org/0000-0001-8668-8325

- Juliano Krug - Universidade Regional de Blumenau - FURB, Santa Catarina, (Brasil). E-mail: juliano.krug@gmail.com Orcid id: https://orcid.org/0000-0002-9143-4394

- Christian Falaster - Universidade Regional de Blumenau - FURB, Santa Catarina, (Brasil). E-mail: christianfalaster@gmail.com Orcid id: https://orcid.org/0000-0001-9502-4475

- lara Regina dos Santos Parisotto - Universidade Regional de Blumenau - FURB, Santa Catarina, (Brasil). Email: iaraparisotto@furb.br Orcid id: https://orcid.org/0000-0002-3162-5826

\section{DISTÂNCIAS INSTITUCIONAIS INFLUENCIAM AQUISIÇÕES INTERNACIONAIS SUL-SUL?}

Stephanie Tonn Goulart Moura, Juliano Krug, Christian Falaster \& lara Regina dos Santos Parisotto Universidade Regional de Blumenau - FURB, Blumenau, SC

\section{DETALHES DO ARTIGO}

\section{Histórico do Artigo:}

Recebido em: 06 setembro 2018

Aceito: 09 de janeiro 2019

Sistema de revisão "Double

blind review"

Editor Científico

Ilan Avrichir

\section{Palavras-Chave}

Negócios Internacionais

Estratégia Internacional

Percentual de Aquisição

Ambiente Institucional

Distância Institucional

\section{RESUMO}

Países diferentes apresentam ambientes institucionais diferentes. Dessa forma, as empresas multinacionais precisam lidar com as dificuldades impostas pelas diferenças entre seu ambiente de origem e o do país onde se inserem. Neste artigo, analisamos os efeitos da distância institucional nas aquisições Sul-Sul. Especificamente, analisamos o efeito da distância institucional sobre a quantidade de participação escolhida nas aquisições internacionais latino-americanas no Brasil. Mais especificamente, analisase o efeito da distância institucional, por meio do percentual de ações adquiridas nas aquisições internacionais. Nossos resultados contribuem para a teoria em negócios internacionais por explicar por que as empresas latino-americanas preferem realizar aquisições totais mesmo em situações de altas distâncias institucionais.

Para citar este artigo:

Moura, S., Krug, J., Falaster, C., \& Parisotto, I. (2019). Do Institutional Distances Influence South-South Cross-Border Acquisitions?.Internext, 14(3), 190-203. doi:http://dx.doi.org/10.18568/internext.v14i3.470 